\title{
Nonprofits and the Promotion of Civic Engagement: A Conceptual Framework for Understanding the "Civic Footprint" of Nonprofits within Local Communities
}

\author{
Micheal L. Shier \& Femida Handy \\ University of Pennsylvania \\ Lindsey M. McDougle \\ Northern Illinois University
}

\begin{abstract}
The literature suggests that nonprofit organizations provide civic benefits by promoting engagement within local communities. However, there exists minimal empirical evidence describing the ways in which nonprofits actually undertake this role. In order to address this omission, we conducted interviews with personnel of nonprofit organizations in one rural community in the United States. Our preliminary findings indicate that nonprofit organizations promote civic engagement through programs and activities that: 1) engage volunteers and donors; 2) bring community members together; 3) collaborate with organizations within and beyond the community; and 4) promote community education and awareness. Together, these findings help to develop a working model to understand the civic footprint of nonprofit organizations with methodological implications for future research that would seek to measure the extent to which nonprofits promote civic engagement.

\section{RÉSUMÉ}

Il est normal de supposer que les associations à but non lucratif favorisent l'engagement du citoyen dans les communautés locales. Cependant, il existe peu de données empiriques sur la manière dont ces associations assument véritablement ce rôle. Pour combler ce manque, nous avons mené des entretiens semi-directifs approfondis auprès du personnel d'associations à but non lucratif dans une petite communauté rurale aux États-Unis. Nos résultats préliminaires indiquent que ces associations motivent les citoyens à s'impliquer quand elles offrent des programmes et des activités qui : 1) intéressent les bénévoles et les donateurs; 2) rassemblent directement ou indirectement les membres de la communauté; 3) collaborent avec d'autres associations tant au sein de la communauté qu'au-delà de celle-ci; et 4) encouragent l'éducation et la conscientisation communautaires. Ces constats aident à établir un modèle pour mieux comprendre la présence civique des associations à but non lucratif dans les communautés et indiquent une piste à suivre pour des recherches futures qui examineraient l'influence de ces associations sur le niveau de participation civique.
\end{abstract}

\section{Keywords / Mots clés}

Nonprofits; Civic engagement; Voluntary associations; Civil society; Civic benefits / Associations à but non lucratif; Engagement civique; Organisations bénévoles; Société civile; Bénéfices civiques 


\section{INTRODUCTION}

Scholars have long theorized about the variety of civic benefits produced by nonprofit organizations in their efforts to promote civic engagement within local communities. For instance, some have proposed that nonprofits promote civic action by encouraging community involvement and maintaining democratic functioning (Milligan \& Conradson, 2006; Putnam, 1993, 2000). Others have suggested that nonprofits enhance the civic conditions of communities by fulfilling demands overlooked by government (Weisbrod, 1986) and by ameliorating the failures of the private market (Hansmann, 1980). Still others have argued that nonprofits add to the civic value of communities by providing an outlet for services where stakeholders, such as consumers and producers, can have a voice (Ben-Ner \& Van Hoomissen, 1992) and undertake religious and secular entrepreneurial initiatives (James, 1987).

Missing from most of this previous scholarship, however, are descriptions of the specific actions undertaken by nonprofits that aid in the promotion of civic engagement. Indeed, although scholars have generally found that the civic contributions of nonprofits are positively linked to the establishment of stronger interpersonal networks among residents (Katz, 1993; Putnam, 1993, 2000), increased civic participation (Putnam, 1993, 2000), and even perceptions about the quality of local government (Brown, 1998; Van Slyke \& Roch, 2004; Wuthnow, 2004), this scholarship does not enhance our understanding of what it is that these organizations do to attain such positive outcomes. To foster the behaviour of civic engagement, it is necessary to first understand what that behaviour involves. The purpose of this research is to understand the specific actions undertaken by nonprofit organizations that promote civic engagement within local communities. To delineate these processes, we conducted in-depth qualitative interviews with nonprofit administrators from a small U.S. Midwestern town. We then developed a conceptual framework outlining the ways that nonprofits collectively influence local community engagement by utilizing a "civic footprint" metaphor to answer our research question: What do nonprofits do to promote civic engagement within local communities? We utilize the "civic footprint" as a way to represent the variety of tangible ways that nonprofits add to the civic life of communities.

\section{LITERATURE REVIEW AND CONCEPTUAL BACKGROUND}

The civic benefits provided by a social entity (such as a nonprofit organization) are often distinct from economic or social benefits. Specifically, civic benefits are those that enhance individual and collective actions intended to further the public good. These actions can strengthen the connection between citizens and community by providing many goods and services that have public good characteristics and that involve members of the community as donors or volunteers (Ben-Ner \& Van Hoomissen, 1992; Hansmann, 1980; James, 1987; Milligan \& Conradson, 2006; Putnam, 1993, 2000; Weisbrod, 1986). Ultimately these actions lead to active participation in community life and the development of greater social ties and trust through civic engagement. Therefore, civic engagement simply refers to the act in which individuals come together for the common benefit of society (Schneider, 2007). More specifically, civic engagement has been defined as the multitude of ways that citizens participate in their communities in order to 1) shape the future of their community and 2) improve the conditions of other community members (Adler \& Goggin, 2005). Therefore, this present study, following Alder \& Goggin (2005), was particularly interested in better understanding the specific ways in which nonprofits support civic engagement in these two areas.

A great deal of literature has focused on the relationship between individual-level characteristics and the implications of these characteristics for civic engagement (Omoto, Snyder, \& Hackett, 2010) and individual development (Flanagan \& Levine, 2010). Some studies, for instance, have focused on youth and adolescents, arguing the importance of early civic engagement for democratic functioning and individual-level development (Henderson, Brown, \& Pancer, 2012; Polson, Kim, Jang, Johnson, \& Smith, 2013; Richards-Schuster \& Dobbie,

ANSERJ To be notified about new ANSERJ articles, click subscribe / s'inscrire ici . 
2011). However, some studies do provide evidence of the importance of the role played by nonprofits in promoting civic engagement (see for example, Putnam, 1993). For instance, Roland Zullo (2013) investigated the relationship between participation in civic organizations and the extent to which individuals participate in local communities or in non-political acts of civic engagement outside of their organization. Zullo found that unions enhanced pro-social behaviour among non-religious and non-union members. Alternatively, Terriquez (2011) found that participation in civic organizations (and labour unions, in particular) did not necessarily mean that individuals would be more civically engaged in other community initiatives.

While there is some contradiction in these findings, they suggest that civic engagement is not only related to individual psychosocial qualities or to the nature of micro-level social networks. Instead, the organizationthrough which the engagement occurs-is likely to play a distinctive role in encouraging civic engagement through participation within local communities (Acheson, 2001).

Similarly, this previous research demonstrates that there is variability in the extent to which nonprofits promote civic engagement. For instance, Schneider (2007) has pointed out that nonprofit organizations do not equally promote civic engagement. Instead they might only promote civic engagement among a particular segment of the population, such as their members. For instance, Shiller (2013) has argued that the way organizations promote civic engagement within communities is through interactions between the organization's personnel and program participants. However, interaction between organizations and community members has tended to focus on micro-level processes of donating and volunteering and the subsequent outcomes for participants (Eliasoph, 2013). Instead, nonprofit organizations promote civic engagement in more complex ways than simply offering volunteer positions or opportunities for community members to donate (Schneider, 2007). Therefore, a more nuanced understanding of the ways that nonprofit organizations connect with community members and enhance civic engagement is needed. Indeed, Handy \& Greenspan (2009) noted that for immigrants' civic engagement, the necessary condition was the existence of organizations that were welcoming to them, such as their ethnic congregations.

\section{Theoretical frameworks of nonprofits and civic engagement}

Three theoretical discourses provide a frame of reference for thinking about the ways that nonprofits actually promote civic engagement in local communities. The first follows from social capital theorizing. Within present scholarship, nonprofits have long been considered integral components of civil society. Indeed, since the time of de Tocqueville (1966), nonprofits have been viewed as the cornerstone of American democracy. The presence of these institutions has often been linked to both a strong civil society and effective democratic functioning (Putnam, 2000). Putnam $(1993,2000)$, for instance, examined the relationship between civil society and democratic functioning by focusing on the role of membership-based nonprofits in the development of social capital. Communities with a higher prevalence of membership associations are thought to foster horizontal relationships of reciprocity and trust, which result in citizens being more willing to act on behalf of the common good. Indeed, Putnam (2000) argues that nonprofits promote solidarity and inclusion and thus are the primary vehicles through which social capital is activated. Thus, from a social capital perspective, nonprofits (particularly those that generate social cohesiveness) are thought to promote civic engagement within communities by fostering, and then, increasing ties among networks of diverse individuals. This then begs the question, what do nonprofit organizations do to increase ties among networks of individuals? One particular way that has been widely documented is by way of creating opportunities for individuals to volunteer in the community (Handy \& Greenspan, 2009).

Other theorists, particularly political economists, argue from a demand perspective. For instance, economic theories on the role and function of nonprofits have suggested that nonprofits provide civic benefits to 


\section{Shier, McDougle, \& Handy (2014)}

communities by correcting for market and government failures. As the argument goes, since markets typically respond to the laws of supply and demand (and often operate based on the willingness of individuals to pay for goods and services), for-profit firms are generally reluctant to provide goods and services with public good characteristics, or which require higher levels of consumer trust. The government and nonprofits then step in to meet these demands (Hansmann, 1980). However, government generally caters to the median voter (Weisbrod, 1986), and thus cannot meet competing expectations of heterogeneous stakeholders.

As a result, nonprofits are thought to enhance civic engagement within communities by responding to the needs of minority groups and meeting the plurality of public demands. Due to the constraint on the distribution of any surpluses generated, nonprofits also, as institutions, generate trust among the public (Handy, Seto, Wakaruk, Mersey, Mejia, \& Copeland, 2010), and their presence gives individuals additional choices of where to purchase goods and services. Furthermore, nonprofits, in their advocacy role for their members or clients, also enhance civic engagement within communities by serving as intermediaries between individuals and various political structures by acting as advocates on behalf of those unable to advocate for themselves (LeRoux, 2007). These functions of nonprofits raise the questions: What types of actions do nonprofits undertake to engage with diverse community members? How do nonprofits engage with community members to meet the needs of minority groups?

Finally, stakeholder theories suggest that nonprofits provide civic benefits to communities in two distinct ways. First, nonprofits provide an outlet for entrepreneurial and stakeholder control in the face of information asymmetries (Ben-Ner \& Gui, 1993; Ben-Ner \& Van Hoomissen, 1992). For example, parents and other demand-side stakeholders may choose to form a nonprofit childcare centre due to lack of trust in for-profits and government agencies, resulting in entrepreneurial stakeholder control in the kind of services they want. Second, nonprofit organizations can provide an outlet for religiously motivated initiatives (James, 1987). For instance, individuals who would prefer to educate their children with particular values (religious or of an ideological manner) can create a school to reflect their values or ideology-an educational setting not likely to be provided by either the government (who must cater to the median voter) or for-profit firms (because of a lack of profits to be made). Thus, according to stakeholder theories, nonprofits promote civic engagement within communities by providing opportunities for minority interests to flourish and be sustained, and give individuals an opportunity to produce particular goods and services. As a result of this theoretical line of thinking, the question that emerges is: What do nonprofits do to bring like-minded citizens together?

These three theoretical discourses are not mutually exclusive categories, but a useful way to understand the primary contributions by scholars from different fields. Social capital theorists argue that nonprofits undertake activities and create opportunities that act to connect citizens together to promote civic engagement. While political economic theorists suggest that nonprofits promote pluralistic society by providing services that address the interests of a wider range of citizens. This essentially creates civic engagement among marginalized segments of the population by engaging community members from diverse backgrounds to promote social inclusion. And, stakeholder theorists argue that civic engagement is promoted by nonprofits through efforts at bringing individuals with similar interests and backgrounds together. One of the reasons for this variability might be because there are many different types of nonprofits with differing functions. However, based on this review of the theoretical literature, it is understood that nonprofits promote civic engagement in several different ways - and in ways that extend beyond discussions of volunteering and donating. To determine how nonprofits do undertake these three roles, we undertook a qualitative research study utilizing one-onone interviews with nonprofit organization leaders in a small U.S. Midwestern town.

ANSERJ To be notified about new ANSERJ articles, click subscribe / s'inscrire ici . 


\section{METHODOLOGY}

Using a qualitative research design, involving in-depth one-on-one interviews with leaders of nonprofits in a small, rural American town, we explored the multiple ways in which nonprofits engaged with community members and investigated their role in the development of civic engagement.

The American town in which the data were collected was a small Midwest community with a population of approximately 2,500 people. According to the 2010 United States census, the majority of residents in the town are Caucasian (approx. 95\%), with less than 1 percent combined reporting that they were African American, Asian, or Native American. ${ }^{1}$ The town is located approximately $190 \mathrm{kms}$ from any larger cities or metropolitan areas. The research setting had 41 nonprofits in the area-listed in the National Center for Charitable Statistics (NCCS).

Studying a single community in-depth has both strengths and weaknesses. On one hand, a single-community analysis allow for rich investigations of the interrelationships among a wide variety of groups and institutions. On the other hand, a single-community analysis always begs the question of representativeness, transferability, and generalizability. In this study, we weighed the trade-offs between conducting an in-depth single-community study versus several studies of the civic footprint of the nonprofit sector across communities. We settled on a single community study using Corbin and Strauss' (2008) construction of "thick and rich" descriptions as our guide.

By focusing on a single community we were able to explore not only individual processes but also context, unencumbered by intervening influences. Thus, the reader is able to make decisions regarding transferability (Erlandson, Harris, Skipper, \& Allen, 1993; Lincoln \& Guba, 1985). For example, in investigating the relationship between campaign efforts and voter turnout, one might be more convinced by a study conducted in a single community than by multiple cross-community studies or individual poll data that rely on myriad, more or less unsatisfactory, controls (Gerber \& Green, 2000).

\section{Table 1: Breakdown of participating organization type and quantity}

\begin{tabular}{|l|c|}
\hline Type of Nonprofit Organization & Quantity \\
\hline Charitable Foundation & 1 \\
\hline Historical Society & 2 \\
\hline Arts and Culture Organization & 2 \\
\hline Community/Leisure Centre & 2 \\
\hline Environmental Organization & 2 \\
\hline Social Club & 2 \\
\hline Religious Congregation & 2 \\
\hline Economic Development Organization & 2 \\
\hline Human Service Organization & 2 \\
\hline Total & 17 \\
\hline
\end{tabular}




\section{Shier, McDougle, \& Handy (2014)}

Table 1 provides a breakdown of the type of nonprofit organizations and the number of organizations of each type that agreed to participate in the study. The representation of nonprofits in this community does not appear unusual, except that there are two historical societies. One reason for two historical societies in such a small town is that there is a heavy emphasis within the local economy on tourism, and the historical elements of the town are instrumental in attracting tourists to the area.

One-on-one interviews were conducted with organization leaders by telephone using a semi-structured interview guide, following standard qualitative methods of interviewing (Fetterman, 2008). Questions focused primarily on identifying ways in which the nonprofit's programs and initiatives promoted engagement within the community. For example, respondents were asked:

- What is the extent of community interaction between your organization and the surrounding neighbourhood/community?

- Can you please describe the relationship between your organization and your local community?

- In what ways does your organization engage with the community and its members?

Interviews lasted between 30 and 60 minutes and were digitally recorded and later transcribed. Qualitative methods of data analysis were utilized, which included a process of analytic induction and constant comparison strategies (see Glasser \& Strauss, 1967; Goetz \& Lecompte, 1984) to detect emergent themes (Charmaz, 2000) and patterns (Fetterman, 2008) within the transcribed interviews. Specifically, emergent themes and patterns were identified with a focus on how organizations support or promote civic engagement within the local community. ${ }^{2}$

In conducting our interviews we reached a saturation of findings; no new themes were emerging from the transcripts after the first 10 interviews, but we continued to interview all 17 nonprofits that had agreed to participate in the study to ensure a wider representation of different types of nonprofits.

\section{FINDINGS}

Our analysis uncovered four primary categories that describe how nonprofits promote and support civic engagement within this community: 1) engaging with volunteers and donors; 2) bringing community members together through direct and indirect services and programs; 3) collaborative engagement activities within and beyond the community; and 4) community education and awareness activities. The breakdown of each theme in the following sections provides some clarity to the specific things that nonprofits actually do to promote civic engagement.

\section{Engaging with volunteers and donors}

By engaging local community members through volunteering and donating activities, nonprofits increase community-level participation among their members, thereby promoting civic engagement. This takes place through programs as well as administrative activities in both direct and indirect ways.

\section{Program activities}

Most respondents describe efforts undertaken to directly engage community members in voluntary activities or direct fundraising in order to support the organization's goals. One respondent at a historical society described: 


\section{Shier, McDougle, \& Handy (2014)}

We rely on the community for donations; we rely on the community for assistance in any activities that we need help [with] outside of our membership. We do have membership, and many community members are members of the organization. (002)

By involving community members in donating and volunteering activities, some nonprofits promote participation in organization activities that have implications for the degree of local community involvement of community members. Similarly, a respondent from a human service nonprofit providing support to elderly people described:

The volunteers do everything. We have people that come in and wrap silverware. We have people that put water and ice in glasses and make the tea or the coffee. We have people that come into the kitchen and help prepare the food. We have people that come in that help do dishes. I have people that do Bingo, I have people that do sing-alongs, and drive vehicles to deliver meals. (015)

As this respondent describes, by engaging community members in voluntary activities with their organization, the community members become active participants in community-based support programs for more marginalized segments of the population. Without these volunteer opportunities, individuals would be less engaged in their local communities.

Nonprofits also undertake activities with other nonprofits, which indirectly promotes community engagement through inter-organizational collaborations. For example, one church provides funding and volunteers to other nonprofits. This respondent described:

We provide some funding and there are many people who are members of the church who volunteer at those organizations or for those projects to keep them going and make sure that they are self-sustaining. (013)

By providing inter-organizational support, the members in one organization become intertwined with those in another organization. As these excerpts demonstrate, nonprofits promote engagement, to varying degrees, by enlisting community members as volunteers or by seeking donations. This also increases social engagement, as volunteers seek out community members and advocate their cause or provide needed services as volunteers.

The variability in the comments is important in assessing the overall extent that an organization supports or promotes civic engagement. Whether or not organizations are able to engage community members to actively volunteer and donate is one aspect of the variability. For instance, some respondents identified that it was difficult to engage volunteers, however others identified that it was relatively easy to encourage engagement among volunteers in the community. For instance, one respondent noted:

We are able to get what we need from community volunteers. Volunteers just fill the need. For example, we had a fundraiser activity last winter. We sponsored the [respondent names sports team] to come in and play against local volunteer teams. We did not have a problem getting these volunteers. (006)

Variability in the number of volunteers is also an important consideration. While the previous respondent described promoting community engagement through recruitment of volunteers to participate in a hockey game 


\section{Shier, McDougle, \& Handy (2014)}

to raise money for a local sports team, other respondents described initiatives that sought to engage larger numbers of community members. For instance, one respondent described:

I did shows that involved everybody in the area, not just [respondent names the town], but the whole area. I included people, I involved them in the shows with musical talents and drama talents, and I composed shows to try to raise funds for this project. I did eight shows. These were very successful and got people involved. ... We had large crowds come to these shows and so it was great interaction with people. (016)

These quotes are examples that demonstrate how nonprofits engage people directly in community-level activities, through direct and indirect means. A comprehensive measure of the role of a nonprofit in promoting civic engagement should consider the multiple ways that organizations involve members of the community and the extent to which volunteers participate. These quotes also provide examples of ways in which nonprofits in this one community promote civic engagement by bringing community members together for a particular cause or issue (a finding that is explained more in the following section). This signifies the importance of thinking about the varying ways that nonprofits can promote civic engagement within local communities. It is not just about providing opportunities to volunteer and donate, because efforts of volunteering and donating can also encourage programs or initiatives that promote community collaborations and activities that involve the community more generally.

Also of importance to note was that respondents described administrative activities associated with volunteering and donating that promote community participation in varying degrees. Through these activities, nonprofits promote awareness of their cause or issue in the local community, which in turn serves to increase the level of civic engagement among community members by providing information to community members about ways to become involved and encouraging engagement with like-minded people in the community. These activities can be direct or indirect. Direct efforts involved recruitment by actively seeking new members or volunteers and/or donations from community members. This happens to varying degrees depending on the organization. For example, one respondent described undertaking minimal efforts to secure membership, resulting in lower impact on community engagement:

We don't make a big deal about membership production, although that's my fault. Because I know there are people that want to join. But we basically just get members by saying, "hey would you like to belong to our organization." ... I have a lady that works in the bank that wants to be a member, and I just haven't had time to go and get her hundred dollars membership fee. (011)

However, some organizations undertook a more active, direct process to enlist members in their organizations. For instance, one respondent described their direct administrative efforts to undertake structured recruitment drives:

We do a membership drive the first of the [every] year, and that's kind of our seed money. We also make sure that we apply for other funding. For example, there are four foundations in our community that we apply for funding from every year; this is an extra $\$ 2,000$ that we would miss out on if we did not follow through. (003)

By undertaking these direct administrative efforts, nonprofits engage with community members on an individual basis, encourage them to participate in the membership activities of organizations, and engage with the wider community about their particular cause or issue.

ANSERJ To be notified about new ANSERJ articles, click subscribe / s'inscrire ici . 
With regard to indirect administrative activities, respondents highlighted several ways in which their activities promote awareness of their organization and their programs, which can provide further impetus for promoting civic engagement by connecting with community members of similar interests. For example, one respondent described that by publishing the organization's meetings in the local newspaper they increase the awareness of their organization within the local community:

We had people who didn't even know we existed; they just thought it was an old church. But we kind of started publishing our board meetings in the paper so people can see what's going on, what we're doing, what we're involved in. (004)

Another indirect activity relates to decisions regarding availability and access to services for community members. One respondent from a community leisure centre described the need to be available to the community by structuring their hours of operation accordingly:

I think our hours that we open during the week are conducive to getting people over here. We open at 5 a.m. in the morning and we close at 10 p.m. at night. We're open 7 days a week. Our hours are a little shorter on Saturday, and Sunday. (005)

Other similar comments made by the respondents often highlighted how activities that support participation of community members include the extent that volunteers or the public are involved and contribute to the activities.

\section{Bringing community members together}

Respondents also identified several ways in which the programs and initiatives by their nonprofit promote civic engagement by bringing community members together. By bringing community members together around specific issues or causes or through community-wide events, civic engagement can be encouraged among citizens. Respondents frequently identified direct and indirect (in relation to their mission) efforts that support bringing people together.

Direct program mandates

Many nonprofits promoted activities directly related to their mission. For instance, one respondent detailed how community arts activities bring people together for workshops and other local events:

The focus of the Arts Council is to promote music and art, and we do entertainment, Arts in the Park, and workshops. We just got through doing an art workshop. One week with high school and adults and the next was elementary kids and the third week was middle school kids. (003)

Another nonprofit undertook a local development initiative with the intention of creating collective community space, and the respondent noted:

We did a project in [names town] where we took a very large section of the [river area] and developed it as walking trails and a destination for people. And that's proved to be a big benefit to the town and an attraction. (001)

ANSERJ To be notified about new ANSERJ articles, click subscribe / s'inscrire ici . 


\section{Shier, McDougle, \& Handy (2014)}

The walking trails provide a space for daily interaction among community members that utilize this outdoor recreational space. And, since it is also a place that individuals from outside the community attend, it acts as a public space in which community members can interact with non-community members.

Several respondents offered similar narratives that captured aspects of their direct service mandates that promoted civic engagement in their communities. For example, environmental organizations brought likeminded people together around issues of land preservation; and historical associations maintained buildings and undertook activities that promoted local culture and provided collective leisure activities within communities. These service delivery functions capture the impact of nonprofits in promoting civic engagement, nevertheless, organizations often promote community engagement indirectly though other initiatives, as we describe below.

\section{Indirect initiatives}

In one indirect initiative, an environmental nonprofit established a scholarship fund for local high school students interested in agriculture, wildlife, or parks management. Through this initiative, students become aware about environmental issues in the community and are able to connect with similarly interested individuals. Similarly, a veterans' nonprofit providing support services to veterans in the community is also involved in multiple civic-minded activities, such as providing funding to local youth organizations to undertake their program mandates. It also provides publicly focused education campaigns that promote awareness, as well as a connection among its members and community members. For instance, the respondent from this veteran's service organization described:

Some of the activities we do, with the help of [respondent names youth organization] is to decorate graves with memorial flags at the cemeteries ... we [also] do other things, such as local parades. We decorate a pick-up or jeep and veterans ride in it, and demonstrate what it was like in our day. (017)

Through these efforts of community engagement, this local nonprofit helps develop an awareness of the issues affecting veterans in the community. By bringing awareness to the situation of veterans in the community, this nonprofit enhances community engagement as it seeks to promote collective action that can address the issues that its members experience.

Another example is the historical society, which also engages with the local community by making its archives publicly available. Similarly, respondents also described hosting information events around particular themes to bring like-minded community members together and to promote community engagement. Others offered their buildings to community groups or clubs to use for meetings and functions:

We have a large enough building and campus area that we are able to enhance what goes on in the community through making our facilities available. If people have to go rent a building for every activity that goes on in here, it would make a pretty significant financial cost for many of the groups. We try to sponsor things to help the community. (009)

There is also an element of diversity within activities. For instance a local arts and culture nonprofit offered programs for individuals of all ages, while a community centre described establishing a $5 \mathrm{~km}$ run/walk for all interested community members. Many of the efforts of the nonprofits were not just about bringing people with similar interests together, but also about creating community events or activities that brought community 


\section{Shier, McDougle, \& Handy (2014)}

members from different backgrounds and experiences together. Many organizations hosted community-level events, as one respondent from a church described:

Once a year we have a very large parade and a community weekend. We give away snowcones and popcorn and balloons for the kids. And then share the Gospel. We want to be a good neighbour in the community and encourage people to serve one another. (009)

Another respondent explained that by creating a community event that involved members from outside the community they facilitated engagement among people locally and beyond:

We put on a powwow for [respondent names local event for an Aboriginal group outside the community]. Some of the people that are on the board participate. And some of our members participate in the pageant and help put on the powwow. (008)

To promote participation and involvement in activities that may otherwise be unaffordable, some nonprofits provide financial support to other organizations or individuals in the community. Providing financial support enables these other organizations to undertake programs and initiatives that promote civic engagement. For instance, one nonprofit described providing financial support to youth programs:

We try to make a difference in the community. Each year we take that money and give some to the [names a youth nonprofit]. We give [names another youth nonprofit] $\$ 100$. We give [names another nonprofit] $\$ 100$ or whatever we can afford. So all the money we take in goes right back to the community here at home. (016)

Together, these quotes show how local nonprofits promote community engagement through direct (i.e., mission related) and indirect (i.e., activities beyond the primary mission) activities. Through these efforts, they bring community members together. In many cases the community members are like-minded, or similarly interested in a particular community issue, but sometimes they are relatively diverse; as in the case of the church and the nonprofit assisting in the powwow. This latter type of community engagement is what Putnam referred to as building bridging social capital (Putnam, 2000). We next examine further and more intentional efforts at building bridging social capital through collaborative engagement among community nonprofits.

\section{Collaborative engagement}

Respondents also described efforts for collaboration among nonprofits that indirectly support or promote civic engagement. Collaborations happened between organizations within the community as well as with organizations outside the local community. By bringing diverse groups of citizens together to address issues within the local community, civic engagement is enhanced.

\section{Inter-organization collaboration}

Some respondents identified working directly with other nonprofits in developing community activities. For instance, one local arts and culture nonprofit worked closely with the local Chamber of Commerce to undertake community-wide initiatives, and a local leisure centre partnered with the local hospital to promote social inclusion of the elderly members in the community. Such partnerships between nonprofits can create an environment in which an increased number of people can become active in community activities. Similarly, one

AMSER To be notified about new ANSERJ articles, click subscribe / s'inscrire ici . 


\section{Shier, McDougle, \& Handy (2014)}

respondent from an environmental nonprofit described how partnerships outside the local community increased civic engagement among people not likely otherwise to meet:

There are two other conservation organizations similar to ours in this area, and all of us are members of each other ... because we are involved in so many things. We're all shooting for the same thing. (007)

Through inter-organizational collaborations, nonprofits with similar missions and mandates can create a concerted effort to align the larger population of similarly interested members of a community. Another respondent (one from a church organization) similarly described its collaborative efforts to undertake a community needs assessment and structure community initiatives based on those identified emerging needs:

We often find out about needs through another organization, so we'll cross talk. For instance, we are the location that sponsors the local blood drive. So we provide a place and the electricity and all the water and whatever else is necessary for the local blood bank to come in once every so many weeks and gather blood for the community. (009)

These inter-organizational collaborative efforts develop long-term initiatives and civic engagement within the community. Furthermore, these collaborative relationships also support the development of a network-based approach that creates civic engagement and locally generated solutions to issues within the community.

\section{Inter-community collaboration}

To a lesser extent, collaboration with surrounding communities also supports civic engagement within local communities by connecting individuals to others outside of their immediate community. For some respondents this theme was captured in descriptions of charitable campaigns organized locally for meeting needs outside the community, as this respondent explained:

We do an initiative called Operation Christmas Child, where we collect items for shoeboxes that are then sent to needy children all over the world. We will collect several hundred of those per year and we have a very active volunteer ministry for that. (009)

For others, inter-community collaboration involved engaging with surrounding communities to promote activities in their own community. One respondent from an economic development nonprofit described:

You know, we get involved in events outside the community that can promote our own area. We went to the [respondent names state-level event], which promotes the [business] interests of the whole state. We've been to some other events like promoting our town. We've also tried to bring in some businesses to the community. (014)

This latter theme only emerged in a few of the interviews; but is instrumental in developing a comprehensive understanding of the multiple ways that nonprofits promote local civic engagement.

\section{Education and awareness}

Finally, respondent's organizations promoted civic engagement within their local community through efforts to raise awareness and educate community members about particular issues. Through education and awareness

ANSER To be notified about new ANSERJ articles, click subscribe / s'inscrire ici . 


\section{Shier, McDougle, \& Handy (2014)}

initiatives, nonprofits create connections between people and issues within their local community. Some may be inspired to act as a result. Through these efforts of education and awareness, nonprofits provide a catalyst to get individuals engaged with local issues or problems, or to engage with the experiences of certain marginalized community members. For example, to promote veteran's issues along with raising civic pride, one respondent described their nonprofit's efforts:

On Veterans Day we present to the 2nd graders across [respondent names area] the United States flag and a stand to put it on. Then on the state's birthday we present each one of those second graders with a state flag for them to display in their own room-to build pride and all that good stuff. (006)

By participating in a program that engages children and youth within this community, this nonprofit is building awareness of issues that some veterans in the community may be experiencing as a result of their service to the country. Other nonprofits described how their programs and initiatives promote local historical and cultural awareness to increase the community's participation in local events. For instance, one respondent described:

We have geological programs about the geology of the area. School children come to the Mission for tours. That actually has dropped off, because they don't have the transportation budgets to bring the kids in. But the curator and volunteers from the [respondent names local nonprofit], often go to the schools. This happens several times a year. (008)

This finding of education and awareness was also present in the previous categories. For instance, a church organization that collaborates in volunteering efforts with a local human service organization also aided in promoting awareness of the social welfare needs of certain people in community to its members. Nonprofits that undertake direct volunteering and donation activities are also promoting awareness of their organizations and the specific issues that they are concerned with to the local community. Essentially, through education and awareness initiatives in local communities, nonprofits indirectly support civic engagement by providing community knowledge, creating a sense of pride, and facilitating a sense of belonging among community members.

\section{A "civic footprint"}

Overall, our findings provide a conceptual framework of a community's civic footprint that more adequately documents the ways that nonprofits promote civic engagement in local communities. Figure 1 delineates our findings of how nonprofits promote local civic engagement; and it is represented in four categories with further delineation into direct and indirect activities.

Unlike previous scholarship, as seen in the literature review, this research focused on organizational level activities and not simply on measuring perceived civic benefits of nonprofit outcomes. Uniquely then, this model of the "civic footprint" captures the impact of nonprofits on community civic development based on activities at the organizational level. Further empirical research could develop measures for this model and pilot the measures with a group of nonprofits. 


\section{Figure 1: Conceptual model of the ways organizations promote or support civic engagement in communities}

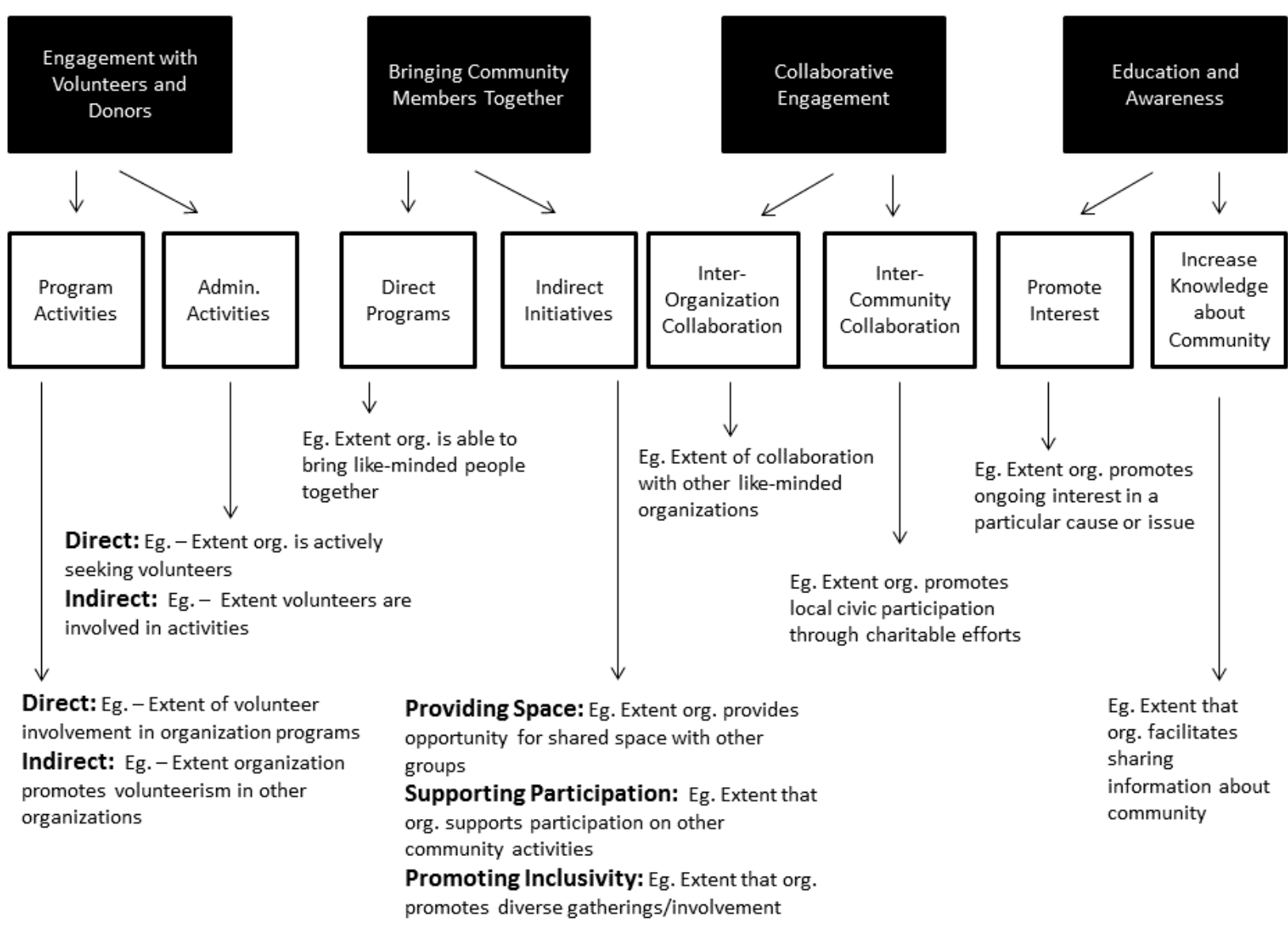

Our analysis, conceptualized in the metaphor of a footprint, is primarily taken from discussion of the "ecological footprint," but with some differences. The ecological footprint was developed as a resource accounting tool to quantify the impact of human activity on the environment by combining heterogeneous components into a composite indicator of ecological impact (Rees, 1992; Kitzes \& Wackemagel, 2008). It represents a standardized measure of human demand of biologically productive land and sea areas in relation to the available supply of Earth's resources (Wackernagel \& Rees, 1996). As the size of the "footprint" increases, the negative environmental impacts increase as well-threatening sustainability for future generations. Despite the conceptual ease of understanding ecological footprint analyses, there are a number of limitations concerning the actual utility of this measure. Kitzes and Wackernagel (2008), for instance, have argued that "it is an overly simplistic view of complex systems" (p. 815). Despite the potential for oversimplification, a footprint analogy provides a strong conceptual metaphor that can easily be understood by the population at large, and presents complicated indicators in an integrated manner.

Applying a similar concept to nonprofit organizations within communities allows for an assessment of the multiple and varied ways these organizations engage with the communities in which they operate. Indeed, through the various 


\section{Shier, McDougle, \& Handy (2014)}

actions undertaken by organizational personnel in relation to their local community context (as identified in Figure 1) we gain a sense of what organizations can do to increase their civic footprint in their local community. Furthermore, conceptualizing the ways in which organizations promote civic engagement can help create a model (to be tested in further research) that measures the extent to which an organization promotes civic engagement within its community.

\section{DISCUSSION AND CONCLUSION}

Respondents in the study identified how their organization's activities support and promote civic engagement, underscoring and illuminating previous scholarship that has argued that nonprofits (collectively) provide benefits to society (Hansmann, 1980; Milligan \& Conradson, 2006; Putnam, 1993, 2000; Weisbrod, 1986). But, unlike previous theoretical literature, we find complex nuances in the processes of how civic engagement is promoted by nonprofits. For instance, stakeholder theory alone might be too narrowly focused on special interests; religious organizations (like those participating in this study) may promote civic engagement among members of their faith group, but they also might promote civic engagement within the wider community by promoting social capital, providing direct social services, or through collaborative efforts with other organizations.

The relationship between nonprofits and civic engagement, according to theories of social capital, may also be too narrowly defined, as they tend to emphasize the nature of social ties at a micro-level of interaction. Nonprofits in this community also engaged in more macro-level practices, similar to those associated with political economic theories of civic benefit. For instance, nonprofits in this study undertook programs and initiatives that were aimed at engaging diverse community members and ensuring minority interests were met, essentially promoting social inclusion of varied community members. However, the findings from this study do highlight the role of nonprofits in creating social networks among community members through direct and indirect efforts of bringing community members together, along with engaging community members in donating and volunteering activities. Certainly, creating social ties was overall the greatest way in which nonprofits promote civic engagement in this local community.

Based on the findings from this study, promoting civic engagement is done in a variety of ways: affording opportunities to volunteer in organizations and in local community activities, through collaboration between members of different organizations, and by undertaking programs and initiatives that allow community members to come together. While social capital theories on the role of nonprofits in promoting civic engagement were found to align with these findings, aspects of stakeholder theories were evident in what respondents described. For instance, organizations undertook programs and initiatives that brought similar, minority interests together and organizations undertook public awareness and education campaigns that sought to align minority interests within the community. Many organizations also sought to enhance social inclusion of minority groups through collaborative efforts between organizations. This latter effort is an example of the political-economic role of nonprofits in promoting civic engagement.

These findings therefore support, in some aspect, social capital, political economic, and stakeholder theories about the varied civic benefits that nonprofits provide in local communities. However, unique to this theoretical literature, our findings highlight direct and indirect ways that nonprofits achieve these benefits for local communities through efforts to enhance civic engagement.

The nature of civic engagement, as we find in our research, is fairly broad and inclusive of inter-organizational collaboration, collaboration with actors outside the local community, generating community awareness, and 
increasing civic and national pride, among others. There is a range of diversity and variability within community activities that underscores the depth and breadth of the level of civic engagement promoted by nonprofits. Therefore, further research could utilize this conceptual framework to measure what we have termed here as the civic footprint of an organization. It is also important to note here that while nonprofits can undertake activities to promote community engagement, it is not necessarily always successful (Eliasoph, 2013). Further research could evaluate these efforts taken by nonprofits to enhance the level of civic engagement within a local community; emphasizing what works and what doesn't.

One place to start would be with organizational practices and processes that are conducive to the development of meaningful civic engagement. For instance, Lelieveldt, Dekker, Volker, and Torenvlied (2009) analyzed data collected from 400 different organizations in the Netherlands and found that the nature of inter-organizational relationships and overall concern for the immediate community were the most important factors contributing to whether organizations participated in activities that aimed at enhancing their local communities. Similarly, Lefkovitz, Pinsoneault, Bonbright, and Nguyen (2013) highlighted the importance of the quality and expertise of the board of directors, available resources, and the focus of programming within organizations as contributing factors to civic engagement outcomes for human service organizations.

In much of this literature, and as was found in the study presented here, the actual organizations are seen as agents of civic engagement and participation (Miller, 2009; Richards-Schuster \& Dobbie, 2011), and there are several factors at the institutional, community, and organizational level that contribute to whether nonprofits engage in efforts to promote civic engagement (Andrews, Ganz, Baggetta, Han, \& Lim, 2010; Koos, 2012; Mulroy, 2004). This present research provides some insight into the ways that organizations promote civic engagement, which could usefully be applied to enhance organizational-level processes and practices that might hinder civic engagement promotion initiatives.

The findings from this study also support the notion that there is variability in the extent to which nonprofits promote civic engagement. For instance, Schneider (2007) has pointed out that nonprofit organizations do not equally promote civic engagement, and while previous research tends to focus on the role of nonprofits in providing outlets for community members to volunteer and donate, the findings here suggest that there are other, more complex ways, that nonprofits promote civic engagement, such as through inter-organizational collaborations or public awareness initiatives. The findings from Handy \& Greenspan (2009), found that immigrant congregation members not only used their volunteering to build social capital within the congregation, but that their volunteering allowed them to interact with community members through congregational outreach activities. The findings from this study help enrich this knowledge base, and the concept of a "civic footprint" helps to create a methodological conceptualization of the varying ways that organizations promote civic engagement.

Although this study serves as a useful addition to prior research on the benefits of, and provides an empirically grounded conceptualization of how nonprofits promote civic engagement, one theme missing from this analysis is the advocacy-based role of organizations in local communities (undoubtedly, an important component of the final category in the findings). Unfortunately, this theme did not come through in any of the respondents' interviews. Further research, therefore, should expand on this thematic category in order to investigate the advocacy-based role of nonprofit organizations and the resulting impact on civic engagement. This omission might be a reflection of the limitations in the sample. However, one outcome of this study is new insight into what future research might shed on the matter. In particular, it would be interesting to know whether a sample drawn from a different kind of community,

ANSERJ To be notified about new ANSERJ articles, click subscribe / s'inscrire ici . 


\section{Shier, McDougle, \& Handy (2014)}

urban for example, that might be more representative of a larger population suggests other thematic categories, or if the findings here are generally consistent with other populations.

Finally, a practical implication of the civic footprint is that it provides us with an easily understood metaphor for understanding the impact of nonprofits in their community-building role. While efforts in the environmental realm are made to shrink the ecological footprint, in our case we promote increasing the civic footprint-and our findings identify various ways that nonprofits achieve this by delineating what goes into the civic footprint. For instance, by increasing volunteer and donor engagement in the community through program activities, promoting collective community gatherings, and fostering collaborative networks with other organizations within and beyond the local community, nonprofit organizations can increase their civic footprint. Administrative policies and organizational practices can then be developed or restructured to support these efforts and to increase the overall civic benefit that an organization has on a local community.

\section{ACKNOWLEDGEMENTS}

We are very grateful to Mrs. Helen Judd who helped facilitate many of the meetings with local associations and generously hosted one of the authors during a field visit. We would also like to thank Isabelle Sun for her research assistant support on this project and the anonymous reviewers for their very helpful comments on an earlier version of this article.

\section{NOTES}

1. It is important to note that the community in which this case is set is atypical of most contemporary American communities on the basis of race, ethnicity, and community size. We thank an anonymous reviewer who pointed this out. This point signifies important limitations when considering the transferability of the findings to other settings. Further research, building off of the findings here, is necessary in a larger, possibly metropolitan, community.

2. Further methodological details are available from the authors on request.

\section{REFERENCES / BIBLIOGRAPHIE}

Acheson, Nicholas. (2001). Service delivery and civic engagement: Disability organizations in Northern Ireland. Voluntas: International Journal of Voluntary and Nonprofit Organizations, 12(3), 279-283.

Adler, Richard P., \& Goggin, Judy. (2005). What do we mean by "civic engagement"? Journal of Transformative Education, 3(3), 236-253.

Andrews, Kenneth T., Ganz, Marshall, Baggetta, Matthew, Han, Hahrie, \& Lim, Chaeyoon. (2010). Leadership, membership, and voice: Civic associations that work. American Journal of Sociology, 115(4), 1191-1242.

Ben-Ner, Avner, \& Gui, Benedetto (Eds.), (1993). The Nonprofit Sector in the Mixed Economy. Ann Arbor, Ml: The University of Michigan Press.

Ben-Ner, Avner, \& Van Hoomissen, Theresa. (1992). An empirical investigation of the joint determination of the size of the for-profit, non-profit and government sectors. Annals of Public and Cooperative Economics, 63(3), 391-415.

Brown, L.D. (1998) Creating social capital: Nongovernment development organizations and intersectoral problem solving. In W.W. Powell \& E.S. Clemens (Eds.), Private action and the public good (pp. 228241). New Haven, CT: Yale University Press. 
Charmaz, Kathy. (2000) Grounded theory: Objectivist and constructionist methods. In N.K. Denzin \& Y.S. Lincolnn (Eds.), Handbook of qualitative research (pp. 509-535). Thousand Oaks, CA: Sage Publications.

Corbin, Juliet, \& Strauss, Anselm (Eds.), (2008). Basics of qualitative research: Techniques and procedures for developing grounded theory. Thousand Oaks, CA: Sage Publications.

de Tocqueville, Alexis. (1966). Democracy in America. New York, NY: Harper \& Row Press. (Originally published in 1835)

Eliasoph, Nina. (2013). The politics of volunteering. Cambridge, UK: Polity Press.

Erlandson, David A., Harris, Edward L., Skipper, Barbara L., \& Allen, Steve D. (1993). Doing naturalistic inquiry: A guide to methods. Newbury Park, CA: Sage Publications.

Fetterman, David M. (2008). Ethnography. In L.M. Given (Ed.), The Sage encyclopedia of qualitative research methods (pp. 288-292). Thousand Oaks, CA: Sage Publications.

Flanagan, Constance, \& Levine, Peter. (2010). Civic engagement and the transition to adulthood. Future of Children, 20(1), 159-179.

Gerber, Alan S., \& Green, Donald P. (2000). The effects of canvassing, direct mail, and telephone contact on voter turnout: A field experiment. American Political Science Review, 94, 653-63.

Glasser, Barney G., \& Strauss, Anselm L. (1967). The discovery of grounded theory: Strategies for qualitative research. New York, NY: Aldine Press.

Goetz, Judith P., \& LeCompte, Margaret D. (1984). Ethnography and qualitative design in educational research. San Diego, CA: Academic Press.

Handy, Femida, \& Greenspan, Itay. (2009). Immigrant volunteering: A stepping stone to integration? Nonprofit and Voluntary Sector Quarterly, 38(6), 956-982.

Handy, Femida, Seto, Stepahnie, Wakaruk, Amanda, Mersey, Brianna, Mejia, Ana, \& Copeland, Laura. (2010). The discerning consumer: Is nonprofit status a factor? Nonprofit and Voluntary Sector Quarterly, 39(5), 866-883.

Hansmann, Henry. (1980). The role of nonprofit enterprise. Yale Law Journal, 89(5), 835-899.

Henderson, Ailsa, Brown, Steven D., \& Pancer, Mark. (2012). Political and social dimensions of civic engagement: The impact of compulsory community service. Politics and Policy, 40(1), 93-130.

James, Estelle. (1987). The nonprofit sector in comparative perspective. In W.W. Powell (Ed.), The nonprofit sector: A research handbook (pp. 397-415). New Haven, CT: Yale University Press.

Katz, Michael B. (1993). Reframing the "underclass" debate. In M.B. Katz (Ed.), The underclass debate: Views from history (pp. 440-477). Princeton, NJ: Princeton University Press.

Kitzes, Justin, \& Wackernagel, Mathis. (2009). Answers to common questions in ecological footprint accounting. Ecological Indicators, 9(4), 812-817.

Koos, Sebastian. (2012). The institutional embeddedness of social responsibility: A multilevel analysis of smaller firms' civic engagement in Western Europe. Socio-Economic Review, 10(1), 135-162.

Lefkovitz, Paul M., Pinsoneault, L.T., Bonbright, D., \& Nguyen, L.T. (2013). Potential best practices for enhancing civic engagement outcomes (field notes). Families in Society, 94(1), 61-63.

Lelieveldt, Herman, Dekker, Karien, Volker, Beate, \& Torenvlied, Rene. (2009). Civic organizations as political actors: Mapping and predicting the involvement of civic organizations in neighbourhood problem solving and coproduction. Urban Affairs Review, 45(1), 3-24.

LeRoux, Kelly. (2007). Nonprofits as civic intermediaries: The role of community-based organizations in promoting political participation. Urban Affairs Review, 42(3), 410-422.

Lincoln, Yvonna S., \& Guba, Egon G. (1985). Naturalistic inquiry. Beverly Hills, CA: Sage Publications.

Miller, Melissa K. (2009). Debating group structure: How local, translocal, and national voluntary organizations promote democracy. The Social Science Journal, 46(1), 47-69. 
Milligan, Christine, \& Conradson, David (Eds.), (2006). Landscapes of voluntarism: New spaces of health, welfare and governance. Bristol, UK: The Policy Press.

Mulroy, Elizabeth A. (2004). University civic engagement with community-based organizations: Dispersed or coordinated models. Journal of Community Practice, 12(3/4), 35-52.

Omoto, Allen M., Snyder, Mark, \& Hackett, Justin D. (2010). Personality and motivational antecedents of activism and civic engagement. Journal of Personality, 76(6), 1703-1734.

Polson, Edward C., Kim, Young-ll, Jang, Sung Joon, Johnson, Byron R., \& Smith, Buster. (2013). Being prepared and staying connected: Scouting's influence on social capital and community involvement. Social Science Quarterly, 94(3), 758-776.

Putnam, Robert. (1993). Making democracy work: Civic traditions in modern Italy. Princeton, NJ: Princeton University Press.

Putnam, Robert. (2000) Bowling alone: The collapse and revival of American community. New York, NY: Simon and Schuster.

Rees, William E. (1992) Ecological footprint and appropriated carrying capacity: What urban economics leaves out. Environment \& Urbanization, 4(2), 121-130.

Richards-Schuster, Katie, \& Dobbie, David. (2011). Tagging walls and planting seeds: Creating spaces for youth civic action. Journal of Community Practice, 19(3), 234-251.

Schneider, Jo Anne. (2013). Connections and disconnections between civic engagement and social capital in community-based nonprofits. Nonprofit and Voluntary Sector Quarterly, 36(4), 572-597.

Shiller, Jessica. (2007). Preparing for democracy: How community-based organizations build civic engagement among urban youth. Urban Education, 48(1), 69-91.

Terriquez, Veronica. (2011). Schools for democracy: Labor union participation and Latino immigrant parents' school-based civic engagement. American Sociological Review, 76(4), 581-601.

Van Slyke, David M., \& Roch, Christine H. (2004). What do they know, and whom do they hold accountable? Citizens in the government-nonprofit contracting relationship. Journal of Public Administration Research and Theory, 14(2), 191-209.

Wackernagel, Mathis, \& Rees, William E. (1996). Our ecological Footprint: Reducing human impact on the Earth. Gabriola Island, BC: New Society Publishers.

Weisbrod, Burton A. (1986). Toward a theory of the voluntary nonprofit sector in a three-sector economy. In S. RoseAckerman (Ed.), The economics of nonprofit institution (pp. 21-44). New York, NY: Oxford University Press.

Wuthnow, R. (2004) Saving America? Faith-based services and the future of civil society. Princeton University Press, Princeton, USA.

Zullo, Roland. (2013). Organized labor's civic niche. Nonprofit and Voluntary Sector Quarterly, 42(4), 781-802.

\section{ABOUT THE AUTHORS / LES AUTEURS}

Micheal L. Shier is a PhD candidate and Doctoral Research Fellow at the School of Social Policy and Practice, University of Pennsylvania, Philadelphia, Pennsylvania, U.S. Email: mshier@sp2.upenn.edu .

Lindsey M. McDougle is Assistant Professor at the School of Public Affairs in the Department of Public Administration, Northern Illinois University, DeKalb, Illinois, U.S. Email: Imcdougle@niu.edu .

Femida Handy is Professor in the School of Social Policy and Practice, University of Pennsylvania, Philadelphia, U.S. Email: fhandy@sp2.upenn.edu .

ANSERJ To be notified about new ANSERJ articles, click subscribe / s'inscrire ici . 